\title{
Pathological Variations Within Xanthomonas campestris pv. mangiferaeindicae Support Its Separation Into Three Distinct Pathovars that Can Be Distinguished by Amplified Fragment Length Polymorphism
}

\author{
N. Ah-You, L. Gagnevin, F. Chiroleu, E. Jouen, J. Rodrigues Neto, and O. Pruvost
}

First, second, third, fourth, and sixth authors: Research plant pathologists and statistician (third author), CIRAD, UMR Peuplements Végétaux et Bioagresseurs en Milieu Tropical CIRAD-Université de la Réunion, Pôle de Protection des Plantes, 7, chemin de l'Irat, 97410 Saint Pierre, La Réunion, France; and fifth author: Research plant pathologist, Lab. Bacteriologia Vegetal, Instituto Biologico, Campinas, SP, Brazil.

Accepted for publication 19 June 2007.

\begin{abstract}
Ah-You, N., Gagnevin, L., Chiroleu, F., Jouen, E., Rodrigues Neto, J., and Pruvost, O. 2007. Pathological variations within Xanthomonas campestris pv. mangiferaeindicae support its separation into three distinct pathovars that can be distinguished by amplified fragment length polymorphism. Phytopathology 97:1568-1577.

Bacterial black spot, caused by Xanthomonas campestris pv. mangiferaeindicae, is an important disease of mango (Mangifera indica). Several other plant genera of the family Anacardiaceae were described as host species for xanthomonads. We studied pathological variations among strains in a worldwide collection from several Anacardiaceae genera. Strains were classified into three pathogenicity groups. Group I strains (from the Old World) multiplied markedly in leaf tissue of mango and cashew (Anacardium occidentale). Group II strains (from Brazil) multiplied markedly in cashew leaf tissue, but not in mango. Moreover,

strains produced black, raised lesions, consistent with the original description of the pathovar, whereas group II strains produced brownish, flat lesions. Group III strains produced a unique syndrome on ambarella (Spondias dulcis) and mombin (Spondias mombin). Based on evolutionary genome divergence derived from amplified fragment length polymorphism (AFLP) data, the three groups were genetically distinct and were related to groups $9.5,9.6$, and 9.4 of $X$. axonopodis identified by Rademaker, respectively. As each group was characterized by unique symptomology and/or host range, we propose that $X$. campestris $\mathrm{pv}$. mangiferaeindicae be split into three pathovars of $X$. axonopodis: $X$. axonopodis pv. mangiferaeindicae, $X$. axonopodis pv. anacardii, and $X$. axonopodis pv. spondiae. Within pv. mangiferaeindicae sensu novo, AFLP data were consistent with that previously published for restriction fragment length polymorphism groups and suggested long-distance movement of the pathogen, likely through propagative material.
\end{abstract} mango leaves inoculated with group I and group II strains exhibited lesions with different morphologies, consistent with variations in symptomology previously reported on mango under field conditions. Group I
Additional keywords: area under disease progress curve, Brazilian pepper, in planta population sizes, leaf lesion morphology.
Mango (Mangifera indica L.) is one of the most cultivated fruits in the world (fifth in worldwide production in 2004 according to the Food and Agriculture Organization of the United Nations [FAO] website). Mango belongs to the family Anacardiaceae, which is mostly represented in tropical and subtropical areas. Mango bacterial canker (MBC) (also called mango bacterial black spot [MBBS]) is an important bacterial disease that affects mango in many countries. This disease was first described in 1915 by Doidge (10) in South Africa but may have originated from India, as the disease was observed in herbarium specimens collected in Bihar in 1881 (25). Because no efficient control can be achieved, MBC causes recurrent problems in the major mango producing regions: Asia, southern and eastern Africa, western Oceania, and the Indian Ocean (15). MBC has been reported in Brazil since 1953 (37) and is a major menace for industries in Central America, which have become increasingly important mango exporters (e.g., Mexico, which ranked first in

\section{Corresponding author: O. Pruvost; E-mail address: olivier.pruvost@cirad.fr}

* The $\boldsymbol{e}$-Xtra logo stands for "electronic extra" and indicates that the online version contains a supplemental table not included in the print edition. This table shows the geographic origins and other characteristics of the 338 strains of $X$. campestris pv. mangiferaeindicae used in this study. The reference strains used, including pathotype strains of relevant pathovars, are also listed.

doi:10.1094/PHYTO-97-12-1568

(C) 2007 The American Phytopathological Society
2004 and represented $23 \%$ of the world exports according to the FAO website). Under climatic conditions favoring MBBS, the disease commonly causes fruit losses of up to $85 \%$ (27).

On mango, the pathogen infects plants through wounds and natural openings. Leaf and fruit lesions are most commonly observed. Symptoms on leaves are raised, black, angular and necrotic, and those on fruits are star-shaped, erumpent with a gummy exudate. Lesions on twigs or branches occasionally occur, most often after hurricanes, but no twig dieback has been reported (15). The pathogen is disseminated on a smaller scale mostly through climatic events such as wind-driven rains or through cultural practices. Long-distance dissemination is due to international movement of contaminated plant material (15). One report from Brazil (43) indicated a unique symptomology on mango leaves, twigs, and fruits in this country. Leaf lesions in Brazil were reported as brownish, flat, angular spots. Fruit lesions were described only on a few cultivars as black, depressed and rounded lesions of irregular sizes. Some lesions only display depressions, with no other external changes, but show an internal pulp decay consisting in tissue discoloration sometimes associated with pulp rot. The pathogen in Brazil also induces unique twig symptoms, i.e., yellow to brown lesions, which subsequently longitudinally crack and evolve as a generalized dieback of the youngest vegetative flush.

The causal agent of $\mathrm{MBC}$ is a gram-negative bacterium, classified in the genus Xanthomonas in the 1970s (11) as X. campestris pv. mangiferaeindicae. In contrast with most xanthomo- 
nads, it produces nonpigmented colonies on agar media (15). However, yellow-pigmented cultures were sporadically isolated in Brazil, South Africa, Florida, and Reunion Island (14). These strains are casual pathogens and should not be classified as pathovar mangiferaeindicae (15).

Reclassification of the genus Xanthomonas by a polyphasic approach including DNA:DNA hybridization did not include the pathovar mangiferaeindicae (49).

The pathovar classification established by Dye et al. (11) and reviewed by Young et al. (50) is an infra-subspecific classification applied to bacterial plant pathogens by reference to their host range or to their capacity to cause distinctive symptoms. Pathogenicity tests are an essential part of this classification. The pathovar classification was primarily developed for plant protection regulators and quarantine officers (50) and has no standing in formal nomenclature regulated by the International Code of Nomenclature of Prokaryotes because it is applied at the infrasubspecific level.

Mango is the host species from which the disease was originally described (10), giving its name to the pathovar (11). But early work also indicated that, when inoculated, mango strains from India were pathogenic to other members of the family Anacardiaceae, such as cashew (Anacardium occidentale L.) and hog plum (syns. ambra or Indian mombin - Spondias mangifera Willd., syn. S. pinnata [J. G. Konig ex L. f.] Kurz.) (25). More recently, xanthomonads producing nonpigmented colonies were described as the causal agent of a bacterial dieback of ambarella (Spondias dulcis Forst., syn. Spondias cytherea Sonn.) in the French West Indies (40) and a black spot of Brazilian pepper (Schinus terebinthifolius Raddi) in Réunion Island (28). In Brazil, a disease caused by xanthomonads was described on cashew and mango $(24,37)$, whereas in the Old World no disease on cashew was reported, even in countries where MBC is present (15). In Brazil, nonpigmented xanthomonads were isolated from mango in several states in the north, northeast, and southeast regions (37), where its importance is globally low but depends on climatic conditions and cultivars (3). No report is available of Brazilian pepper infected by an xanthomonad in Brazil.

Phenotypic (29), isozyme (47), and restriction fragment length polymorphism (RFLP) analyses (using an hrp gene cluster as probe) (14) suggested that strains isolated in the Old World on mango and Brazilian pepper are closely related. These strains were distantly related to mango strains isolated in Brazil, strains from ambarella, and yellow-pigmented strains from mango. Two RFLP probes, an avirulence (avr) gene (avrXa10) cloned from $X$. oryzae pv. oryzae and belonging to the $a v r B s 3$ gene family (17) and an insertion sequence (IS1595) from X. campestris pv. mangiferaeindicae were used to further study the genetic variability among $X$. campestris pv. mangiferaeindicae strains collected from different geographic regions. The $a v r$ probe primarily distinguished strains on the basis of the host from which they originated (mango or Brazilian pepper), whereas the IS probe distinguished strains based on the country from which they originated (14).

Because pv. mangiferaeindicae is of considerable economic significance worldwide, we examined the genetic diversity (using amplified fragment length polymorphism [AFLP]) and the pathological variations of a worldwide collection of strains from selected genera in the family Anacardiaceae. In the present study, we show that $X$. campestris pv. mangiferaeindicae is a genetically and pathologically complex pathovar. As recommended by Young et al. (50), we assessed associations between pathogenicity characters and AFLP data, a technique suitable for pathovar identification purpose (33). Some strains had a unique host range and/or differed in terms of symptom morphology and ability to multiply in host tissue. Therefore, we propose to reclassify $X$. campestris pv. mangiferaeindicae into three pathovars.

\section{MATERIALS AND METHODS}

Bacterial strains and DNA extraction. A total 338 strains of $X$. campestris pv. mangiferaeindicae were used in this study.

Strains were stored at $-80^{\circ} \mathrm{C}$ on beads in cryovials (Microbank Prolab Diagnostics, Austin, TX) and also freeze-dried for longterm storage. Cultures were grown routinely on YPGA (7 $\mathrm{g}$ of yeast extract, $7 \mathrm{~g}$ of peptone, $7 \mathrm{~g}$ of glucose, and $15 \mathrm{~g}$ of agar liter $^{-1} ; 20 \mathrm{mg}$ of propiconazole liter ${ }^{-1}$ ) at $28^{\circ} \mathrm{C}$. Some strains included in this study were deposited in the Collection Française de Bactéries Phytopathogènes (CFBP, INRA, Angers, France), the Belgian Coordinated Collections of Micro-Organisms, (BCCM/ LMG, University of Ghent, Belgium), and the National Collection of Plant Pathogenic Bacteria (NCPPB, CSL, York, United Kingdom).

Genomic DNA was extracted from bacteria with the DNeasy tissue kit (Qiagen, Courtaboeuf, France) following the manufacturer's instructions, and DNA concentrations were estimated by fluorometry (TKO 100 Fluorometer, Hoefer, San Francisco).

AFLP analysis. All strains of $X$. campestris pv. mangiferaeindicae were submitted to AFLP analysis. To test the reproducibility of the AFLP technique, two independent DNA extractions were used, and strain CFBP 2933 was used as a control in each AFLP experiment. Polymerase chain reaction (PCR) analyses were performed in a GeneAmp PCR system 9700 thermocycler (Applied Biosystems, Courtaboeuf, France). Adaptors and PCR primers were synthesized by Applied Biosystems (Table 1).

AFLP analysis was performed as described previously (18). The selective amplifications were performed using unlabeled Msp I+1 (A, C, T, or G) primers and 5'-labeled-SacI+C primers (fluorochromes used: 6-FAM, VIC, NED, and PET, respectively).

The presence and absence of fragments were scored as a binary matrix. A dissimilarity matrix using Jaccard index was calculated and a weighted neighbor-joining tree (42) was built using DARWIN 5.0 software (26). The robustness of the tree was assessed by bootstrap analysis with the same software $(1,000$ samplings).

Metric multidimensional scaling (MDS) was used to represent distances between strains, based on the Jaccard dissimilarity matrix. MDS transforms a distance matrix (which cannot be analyzed by eigen-decomposition) into a cross-product matrix and then solves the eigenvector problem to find the coordinates of individuals, so that distortions to the distance matrix are minimized. As in principal component analysis, individuals are projected into $n$ dimensions (1). This technique is becoming popular for analyzing ecological data $(5,7)$. MDS was performed using the cmd-scale function in the R software (version 2.3.1; R Development Core Team, Vienna, Austria).

AFLP patterns of strains of $X$. campestris pv. mangiferaeindicae were compared with those of the type strain of $X$. cam-

TABLE 1. Amplified fragment length polymorphism primers and adaptors used in this study

\begin{tabular}{ll}
\hline Primers/adaptors & Sequence $5^{\prime}>$ 3' $^{\prime}$ \\
\hline Ligation adaptors & \\
A1MSP & GACGATGAGTCCTGAG \\
A2MSP & CGCTCAGGACTCATC \\
A1SAC & CTCGTAGACTGCGTACAAGCT \\
A2SAC & TGTACGCAGTCTACG \\
Preamplification primers & \\
PMSP & GATGAGTCCTGAGCGG \\
PSAC & TAGACTGCGTACAAGCTC \\
Selective amplification primers & \\
$M s p I+1$ selective nucleotide & GATGAGTCCTGAGCGG + A, C, T, or G \\
5'-labeled SacI+C & 6-FAM - TAGACTGCGTACAAGCTCC \\
& VIC - TAGACTGCGTACAAGCTCC \\
& NED - TAGACTGCGTACAAGCTCC \\
& PET - TAGACTGCGTACAAGCTCC \\
\hline
\end{tabular}


pestris and $X$. axonopodis (obtained from LMG as LMG 568 and LMG 982, respectively). AFLP patterns of other pathovars of $X$. axonopodis belonging to groups 9.1 to 9.6 sensu Rademaker et al. (34) were also compared with strains isolated from the family Anacardiaceae. For such comparisons, evolutionary genome divergences (EGD), expressed as the number of nucleotide substitutions per site, were calculated from Dice similarity index and corrected to account for unobserved substitutions by using the standard Jukes-Cantor model, which assumes equal substitution rates between all pairs of bases (22).

Pathogenicity tests on mango, cashew, and Brazilian pepper. Strains used for pathogenicity tests are indicated in Table 2 (comparison of strains identified as $X$. axonopodis groups 9.4, 9.5, and 9.6) and Table 3 (comparison of a larger set of strains identified as $X$. axonopodis group 9.5 from two different host species). Brazilian pepper, mango cvs. Maison Rouge and Haden, and/or cashew were used for inoculations. Bacterial suspensions containing approximately $10^{5} \mathrm{CFU} \mathrm{ml}^{-1}$ were obtained by 10 -fold dilutions of spectrophotometrically adjusted suspensions $(0.06$ optical density $[\mathrm{OD}]$ at $600 \mathrm{~nm} \approx 10^{8} \mathrm{CFU} \mathrm{m} \mathrm{m}^{-1}$ ) prepared from 18 -h-old cultures on YPGA. Suspensions were infiltrated ( 0.3 to $0.4 \mathrm{~cm}^{2}$ ) into the mesophyll of mature leaves from the youngest vegetative flush. For each strain, 10 inoculation points were performed on each of three leaves on different plants. Each experiment was replicated once. Plants were placed in growth chambers at $30 \pm 1{ }^{\circ} \mathrm{C}$ day and $26 \pm 1{ }^{\circ} \mathrm{C}$ night and $95 \pm 5 \%$ relative humidity for 35 days with a photoperiod of $12 \mathrm{~h}$. All inoculated leaves were examined daily for 20 days (comparisons of AFLP groups 9.5 and 9.6) or 25 days (comparisons of strains within AFLP group 9.5) for lesion development (i.e., the number of visible lesions per leaf).

$X$. campestris pv. mangiferaeindicae population sizes in lesions from the same host species were estimated 35 days after inoculation (dai) for strains listed in Tables 2 and 3. For each strainhost combination, eight leaf fragments $\left(\approx 1 \mathrm{~cm}^{2}\right)$ collected at inoculation sites were sampled. Leaf fragments were excised from the leaf blade, surface-sterilized with $95 \%$ ethanol, and individually homogenized in $4.5 \mathrm{ml}$ of $0.01 \mathrm{M}, \mathrm{pH} 7.2$, Sigma 7-9

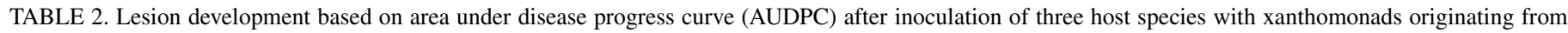
Anacardiaceae and identified as amplified fragment length polymorphism (AFLP) groups 9.4, 9.5, and 9.6 of Xanthomonas axonopodis ${ }^{\mathrm{u}}$

\begin{tabular}{|c|c|c|c|c|c|c|}
\hline \multirow[b]{2}{*}{ Strain } & \multirow[b]{2}{*}{ Host of origin } & \multirow{2}{*}{$\begin{array}{l}\text { Proposed pathovar } \\
\text { designation }^{\mathrm{v}}\end{array}$} & \multirow[b]{2}{*}{ AFLP group $^{w}$} & \multicolumn{3}{|c|}{ AUDPC species inoculated } \\
\hline & & & & Mango & Cashew & Brazilian pepper \\
\hline CFBP $1716^{x}$ & Mango & mangiferaeindicae (I) & 9.5 & $101.3(12.9)^{\mathrm{y}} \mathrm{c}^{\mathrm{z}}$ & $155.3(6.6) \mathrm{a}$ & $151.5(12.4) b c$ \\
\hline JK147-1 & Mango & mangiferaeindicae (I) & 9.5 & $95.8(12.3) \mathrm{d}$ & $151.7(2.1) \mathrm{a}$ & $150.5(14.1) b c$ \\
\hline A5-1 & Mango & mangiferaeindicae (I) & 9.5 & $95.0(15.5) \mathrm{d}$ & $144.0(3.2) \mathrm{b}$ & $148.5(11.9) b c$ \\
\hline CFBP 2939 & Brazilian pepper & mangiferaeindicae (I) & 9.5 & $119.0(13.4) b c$ & $150.3(2.4) \mathrm{a}$ & $146.0(9.4) \mathrm{c}$ \\
\hline CFBP 2912 & Mango & anacardii $(\mathrm{II})$ & 9.6 & $123.8(4.6) b$ & $145.8(4.2) b$ & $167.7(6.7) \mathrm{a}$ \\
\hline CFBP 2913 & Mango & anacardii (II) & 9.6 & $123.3(3.9) \mathrm{b}$ & $152.3(3.0) \mathrm{a}$ & $169.7(6.4) \mathrm{a}$ \\
\hline CFBP 2914 & Mango & anacardii (II) & 9.6 & $124.0(4.0) \mathrm{b}$ & $154.2(5.2) \mathrm{a}$ & $160.8(10.5) \mathrm{ab}$ \\
\hline JY542 & Cashew & anacardii (II) & 9.6 & $136.8(7.3) \mathrm{a}$ & $149.8(0.4) \mathrm{a}$ & $160.3(6.7) \mathrm{ab}$ \\
\hline LA98 & Cashew & anacardii (II) & 9.6 & $138.7(5.4) \mathrm{a}$ & $151.2(2.5) \mathrm{a}$ & $163.7(11.9) \mathrm{ab}$ \\
\hline LA99 & Cashew & anacardii (II) & 9.6 & $136.2(4.5) \mathrm{a}$ & $150.2(4.9) \mathrm{a}$ & $169.5(5.7) \mathrm{a}$ \\
\hline LA100 & Cashew & anacardii (II) & 9.6 & $124.8(2.2) b$ & $152.2(4.8) \mathrm{a}$ & 160.8 (7.9) ab \\
\hline LA101 & Cashew & anacardii (II) & 9.6 & $126.5(3.9) b$ & $150.3(5.6) \mathrm{a}$ & $161.7(11.0) \mathrm{ab}$ \\
\hline LA102 & Cashew & anacardii (II) & 9.6 & $124.5(2.4) b$ & $152.8(4.3) \mathrm{a}$ & $158.7(12.8) \mathrm{ab}$ \\
\hline LA103 & Cashew & anacardii (II) & 9.6 & $124.7(5.0) \mathrm{b}$ & $150.3(4.8) \mathrm{a}$ & $161.0(6.7) \mathrm{ab}$ \\
\hline CFBP 2547 & Ambarella & spondiae (III) & 9.4 & $107.3(13.9) \mathrm{cd}$ & $121.2(4.9) \mathrm{c}$ & $97.0(31.7) \mathrm{d}$ \\
\hline
\end{tabular}

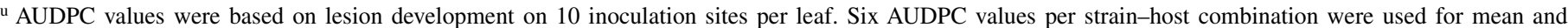
standard deviation calculation.

${ }^{v}$ Pathogenicity groups are given in parenthesis.

w This study. Group numbers as defined in Rademaker et al. $(33,34)$.

${ }^{x}$ Pathotype strain.

y Values between parentheses are standard deviations, based on two replicated experiments.

${ }^{\mathrm{z}}$ Strain comparisons based on Mann-Whitney tests. AUDPC values followed by the same letter(s) are not significantly different $(P=0.05)$.

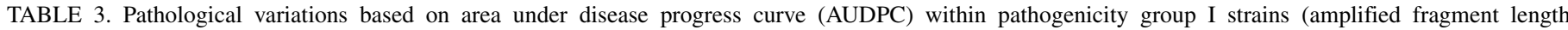
polymorphism group 9.5) after inoculation of mango and Brazilian pepper ${ }^{v}$

\begin{tabular}{|c|c|c|c|c|c|}
\hline \multirow[b]{2}{*}{ Strain } & \multirow[b]{2}{*}{ Host of origin } & \multirow[b]{2}{*}{ Country of origin } & \multirow{2}{*}{$\begin{array}{l}\text { Restriction fragment length } \\
\text { polymorphism group }^{\mathrm{w}}\end{array}$} & \multicolumn{2}{|c|}{ AUDPC species inoculated } \\
\hline & & & & Mango & Brazilian pepper \\
\hline CFBP 2935 & Mango & Australia & $\mathrm{C}$ & $165.3(10.5)^{x} b^{y}$ & $181.8(10.1) \mathrm{a}$ \\
\hline CFBP $1716^{z}$ & Mango & India & $\mathrm{C}$ & $151.3(12.9) \mathrm{bc}$ & $181.5(12.4) \mathrm{a}$ \\
\hline JK147-1 & Mango & Philippines & $\mathrm{B}$ & $145.8(12.3) \mathrm{c}$ & $180.5(14.1) \mathrm{ab}$ \\
\hline A5-1 & Mango & Réunion & $\mathrm{A}$ & 145.5 (18.6) bc & $165.8(2.1) \mathrm{bc}$ \\
\hline CFBP 2932 & Mango & Réunion & A & $143.8(21.2) \mathrm{bc}$ & $167.5(7.9) \mathrm{b}$ \\
\hline CFBP 2933 & Mango & Réunion & $\mathrm{C}$ & $143.2(23.1) b c$ & $178.0(20.7) \mathrm{ab}$ \\
\hline JV1121 & Mango & South Africa & ND & $164.0(14.5) \mathrm{b}$ & $181.5(7.1) \mathrm{a}$ \\
\hline CFBP 2938 & Brazilian pepper & Réunion & $\mathrm{D}$ & $194.4(5.9) \mathrm{a}$ & $164.7(4.7) \mathrm{bc}$ \\
\hline CFBP 2939 & Brazilian pepper & Réunion & $\mathrm{D}$ & $182.5(7.6) b$ & $149.7(15.6) \mathrm{d}$ \\
\hline CFBP 2940 & Brazilian pepper & Réunion & $\mathrm{D}$ & $173.5(17.1) b$ & 155.5 (19.6) bcd \\
\hline JP742 & Brazilian pepper & Réunion & $\mathrm{D}$ & $133.3(18.2) \mathrm{c}$ & $160.3(9.2) \mathrm{cd}$ \\
\hline JP758 & Brazilian pepper & Réunion & $\mathrm{D}$ & $181.0(10.5) b$ & $155.3(12.7) \mathrm{cd}$ \\
\hline
\end{tabular}

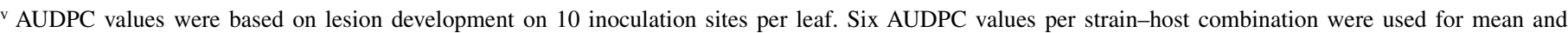
standard deviation calculation.

${ }^{w}$ From Gagnevin and Pruvost (14); ND, not determined.

${ }^{x}$ Values between parentheses are standard deviations, based on two replicated experiments.

y Strain comparisons based on Mann-Whitney tests. AUDPC values followed by the same letter(s) are not significantly different $(P=0.05)$.

${ }^{z}$ Pathotype strain. 
buffer (Sigma, Saint Quentin Fallavier, France) with an Ultraturax T25 homogenizer (Janke \& Kunkel, IKA Labortechnik, Staufen, Germany). Aliquots of the homogenized suspensions and of 10fold dilutions obtained from the suspensions were plated on semiselective media (32) with the Spiral System device (Interscience, Saint Nom la Bretèche, France). We used three media (KC and NCTM3 semiselective media [32] and modified Wilbrink medium [39]), depending on the strains we compared. Bacterial population sizes were based on enumeration of $X$. campestris pv. mangiferaeindicae-like colonies (starch hydrolysis was checked on doubtful colonies).

Data analysis. Area under disease progress curve (AUDPC) values were calculated for each inoculated leaf (8). Variance homogeneity was examined using the Bartlett test. This criterion was not met by some data sets. Therefore, nonparametric tests (Kruskal-Wallis and pairwise Mann-Whitney) were performed using R statistical package (version 2.3.1; R Development Core Team, Vienna, Austria).

Bacterial population sizes were log-transformed to stabilize sample variances. Variance homogeneity was examined using the Bartlett test. This criterion was not met for some data sets, as data derived from strains with a lower in planta growth ability displayed higher sample variance values. Therefore, nonparametric tests (Kruskal-Wallis and Mann-Whitney) were performed using the $\mathrm{R}$ statistical software (version 2.3.1; R Development Core Team).

Pathogenicity tests on ambarella and mombin. Strains CFBP 2547, CFBP 2623 (isolated from ambarella in the French West Indies), as well as $X$. campestris pv. mangiferaeindicae CFBP 1716 (pathotype strain isolated from mango in India) and CFBP 2913 (isolated from mango in Brazil) were used for inoculation. Bacterial suspensions containing approximately $10^{8} \mathrm{CFU} \mathrm{m}{ }^{-1}$

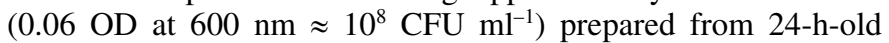
cultures on YPGA were used. Inoculations were performed by wounding a herbaceous part of the main stem with a sterile scalpel and depositing a $10-\mu \mathrm{l}$ droplet on the wound. For each strain, three seedlings ( 3 to 5 months old) of both species were inoculated. Each experiment was replicated once. Plants were placed in growth chambers at $28 \pm 1{ }^{\circ} \mathrm{C}$ and $95 \pm 5 \%$ relative humidity for 30 days with a photoperiod of $12 \mathrm{~h}$. All inoculated plants were examined weekly for lesion development. At the end of each experiment, reisolation of the pathogen from twig symptoms was performed on YPGA or modified Wilbrink medium (39).

\section{RESULTS}

Genetic relatedness among pathovar mangiferaeindicae strains and outgroups. EGD values were calculated from AFLP data and indicated that xanthomonads associated with the family Anacardiaceae were highly heterogeneous and comprised three main groups of strains. The first group consisted of strains isolated from mango and Brazilian pepper and originated from countries in the Old World. The second group consisted of strains isolated from both mango and cashew and originated from Brazil. The third group consisted of strains isolated from ambarella and originated from the French West Indies. Examples of EGD values between selected strains from the three groups and other Xanthomonas strains are shown in Figure 1.

EGD values between strains inside a group ranged between 0.001 and 0.014 nucleotide substitutions per site for group I, 0.003 and 0.022 nucleotide substitutions per site for group II, and there was no polymorphism between the two strains that constituted group III. Minimal EGD values between group I versus group II and group III strains were 0.062 and 0.116 nucleotide substitutions per site, respectively. Similarly, the minimal EGD value between group II versus group III strains was 0.103 nucleotide substitutions per site.

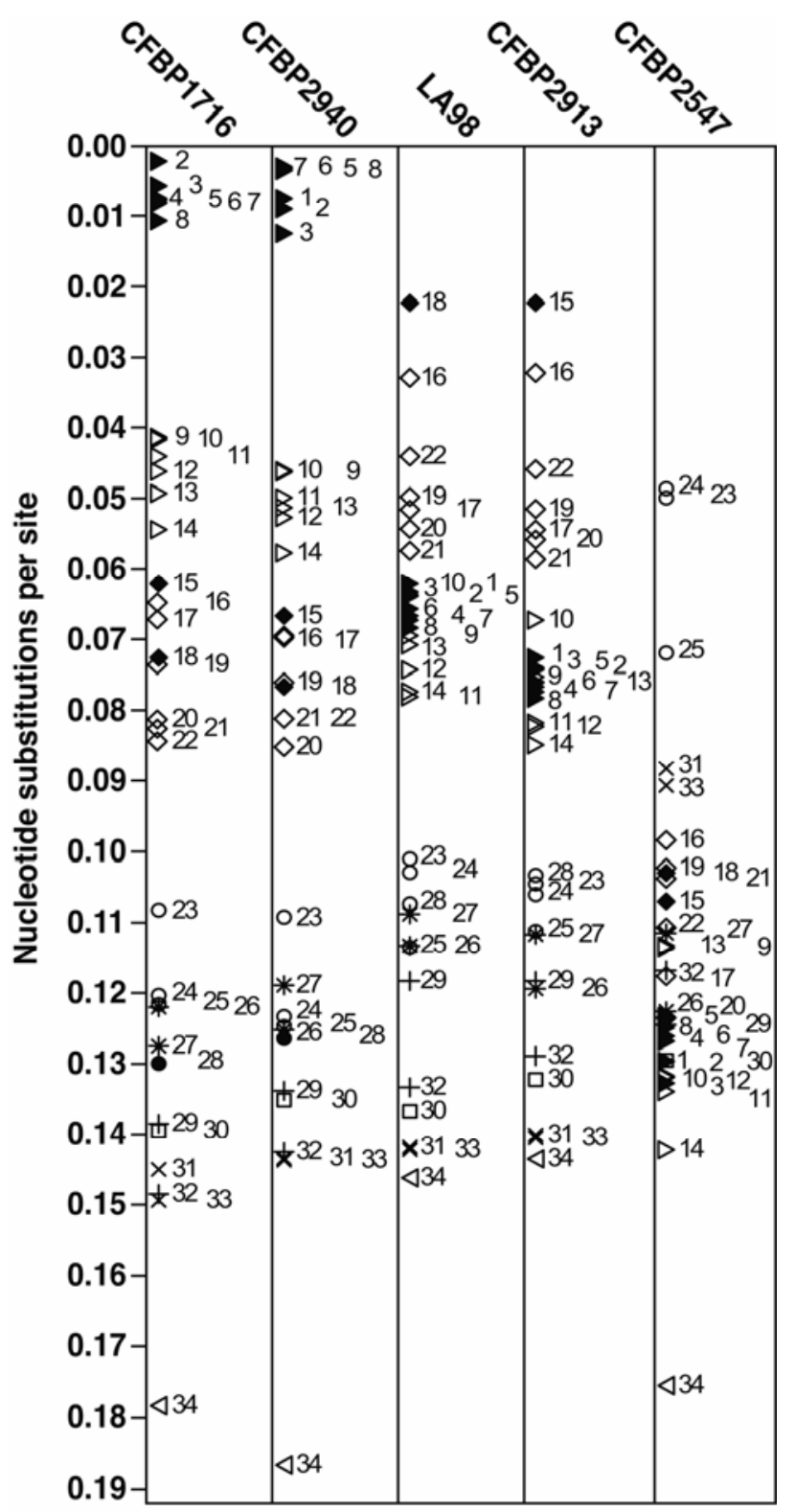

Fig. 1. Representation of genetic distances based on evolutionary genome divergence (EGD), expressed as the number of nucleotide substitutions per site and calculated between xanthomonads isolated from Anacardiaceae, strains representative of groups 9.1 to 9.6 of Xanthomonas axonopodis, and the type strain of $X$. campestris. Symbols are as follows: $\times$, group $9.1 ; *$, group $9.2 ;+$, group $9.3 ; \bigcirc$, group $9.4 ; \triangleright$, group $9.5 ; \diamond$, group $9.6 ; \square, X$. campestris; and $\triangleleft$, unknown species. Symbols filled with solid black are for strains isolated from the family Anacardiaceae. Strain numbers are as follows: 1, CFBP 1716 (pathotype strain of pv. mangiferaeindicae - from mango - 9.5); 2, CFBP 2917 (from mango - 9.5); 3, JR749 (from mango - 9.5); 4, CFBP 2940 (from Brazilian pepper - 9.5); 5, JR606-2 (from Brazilian pepper - 9.5) 6, CFBP 2938 (from Brazilian pepper - 9.5); 7, JR606-1 (from Brazilian pepper 9.5); 8, JR537-6 (from Brazilian pepper - 9.5); 9, CFBP 2525 (X. a. pv. citri - 9.5); 10, LMG 558 (X. a. pv. cajani - 9.5); 11, LMG 712 (X. a. pv. glycines - 9.5); 12, LMG 761 (X. a. pv. malvacearum - 9.5); 13, LMG 9045 (X. a. pv. clitoriae - 9.5); LMG 8014 (X. a. pv. phaseoli - 9.4); 14, LMG 937 (X. a. pv. vitians - 9.5); 15, LA98 (from cashew - 9.6); 16, CFBP 2866 (X. a. pv. aurantifolii - 9.6); 17, LMG 867 (X. a. pv. sesbaniae - 9.6); 18, CFBP 2913 (from mango - 9.6); 19, LMG 8021 (X. a. pv. rhynchosiae - 9.6); 20, LMG 828 (X. a. pv. vignicola - 9.6); 21, LMG 936 (X. a. pv. vigniaeradiatae - 9.6); 22, LMG 7511 (X. a. pv. phaseoli var. fuscans - 9.6); 23, LMG 7455 (X. a. pv. phaseoli 9.4); 24, LMG 695 (X. a. pv. dieffenbachiae - 9.4); 25, CFBP 2603 (X. a. pv. manihotis - 9.4); 26, CFBP 6369 (X. a. pv. allii - 9.2); 27, LMG 811 (X. a. pv. patelii - 9.2); 28, CFBP 2547 (from ambarella - 9.4); 29, LMG 899 (X. a. pv. vasculorum - 9.3); 30, LMG $568^{\mathrm{T}}$ (X. c. pv. campestris - type strain of X. campestris); 31, LMG 551 (X. a. pv. begoniae - 9.1); 32, LMG 7303 (X. a. pv. begoniae - 9.1); 33, LMG $982^{\mathrm{T}}$ (X. a. pv axonopodis - type strain of $X$. axonopodis 9.3); and 34, CFBP 2924 (mango from Brazil, yellow pigmented colonies). 
EGD values calculated between each group defined in the present study and reference strains of $X$. axonopodis and $X$. campestris (Fig. 1) indicated the closest $X$. axonopodis subgroups defined by Rademaker et al. (34). Group I strains were genetically related to the $X$. axonopodis group 9.5, with EGD values ranging between 0.041 and 0.058 nucleotide substitutions per site (with $X$. axonopodis pv. citri [CFBP 2525] and $X$. axonopodis pv. vitians [LMG 937], respectively). Group II strains were closely related to the $X$. axonopodis group 9.6, with EGD values ranging between 0.032 and 0.059 nucleotide substitutions per site (for $X$. axonopodis pv. aurantifolii [CFBP 2866] and X. axonopodis pv. vignaeradiatae [LMG 936], respectively). Group III strains were most closely related to strains belonging to the $X$. axonopodis group 9.4, with EGD values ranging between 0.048 and 0.072 nucleotide substitutions per site (with $X$. axonopodis pv. dieffenbachiae [LMG 695] and X. axonopodis pv. manihotis [CFBP 2603], respectively).

The EGD value between the pathotype strain of $X$. campestris pv. mangiferaeindicae (CFBP 1716) and the type strains of $X$. axonopodis (LMG 982) and X. campestris (LMG 568) were 0.149 and 0.140 nucleotide substitutions per site, respectively (Fig. 1).

Genetic diversity within group I strains from AFLP data. One hundred and thirty-seven markers obtained by pooling data derived from the four selective primers were used for analysis. Sizes of the selected bands ranged from 47 to $408 \mathrm{bp}$, and 37 bands of 137 (27\%) were polymorphic. The polymorphic markers allowed the identification of 125 haplotypes among the 328 group I strains. The overall genetic diversity within group I strains was low, with maximal Jaccard dissimilarity values around 0.15 (i.e., EGD values of 0.014 nucleotide substitutions per site). Most branches in the neighbor-joining tree were characterized by low (i.e., $\leq 70 \%$ ) bootstrap values. Seven subgroups were supported by moderately robust bootstrap values. The first subgroup (bootstrap $84 \%$ ) was composed of mango strains originating from the Comoros. Two subgroups (bootstrap of 78\%) were composed of mango strains originating from five Asian countries (Japan, Philippines, and Taiwan, Thailand, and India) (Fig. 2A). Other subgroups with bootstrap values $>70 \%$ were composed of mango strains isolated in Réunion Island. Based on the neighbor-joining tree (Fig. 2A) and the representation of axes 1 and 2 of the MDS (Fig. 2B), the population structure derived from AFLP analysis is partly congruent with that previously described by RFLP. Strains from mango or Brazilian pepper were not clearly separated.

Pathogenicity tests on mango, cashew, and Brazilian pepper. All strains listed in Table 2 induced black lesions after inoculation on mango, cashew, and Brazilian pepper, with two distinct morphologies. Mango leaves inoculated with strains originating from mango and identified as group I (which are genetically related to $X$. axonopodis group 9.5) showed raised, black, angular lesions. Brazilian pepper and cashew leaves inoculated with the same strains showed flat, necrotic, angular lesions. All other plant-strain combinations produced necrotic flat lesions. Cashew leaves showed an extensive water soaking (which developed to form black necrotic lesions) only when inoculated with group II strains (which are genetically related to $X$. axonopodis group 9.6). Similarly, Brazilian pepper leaves displayed an extensive water soaking (which developed to form black necrotic
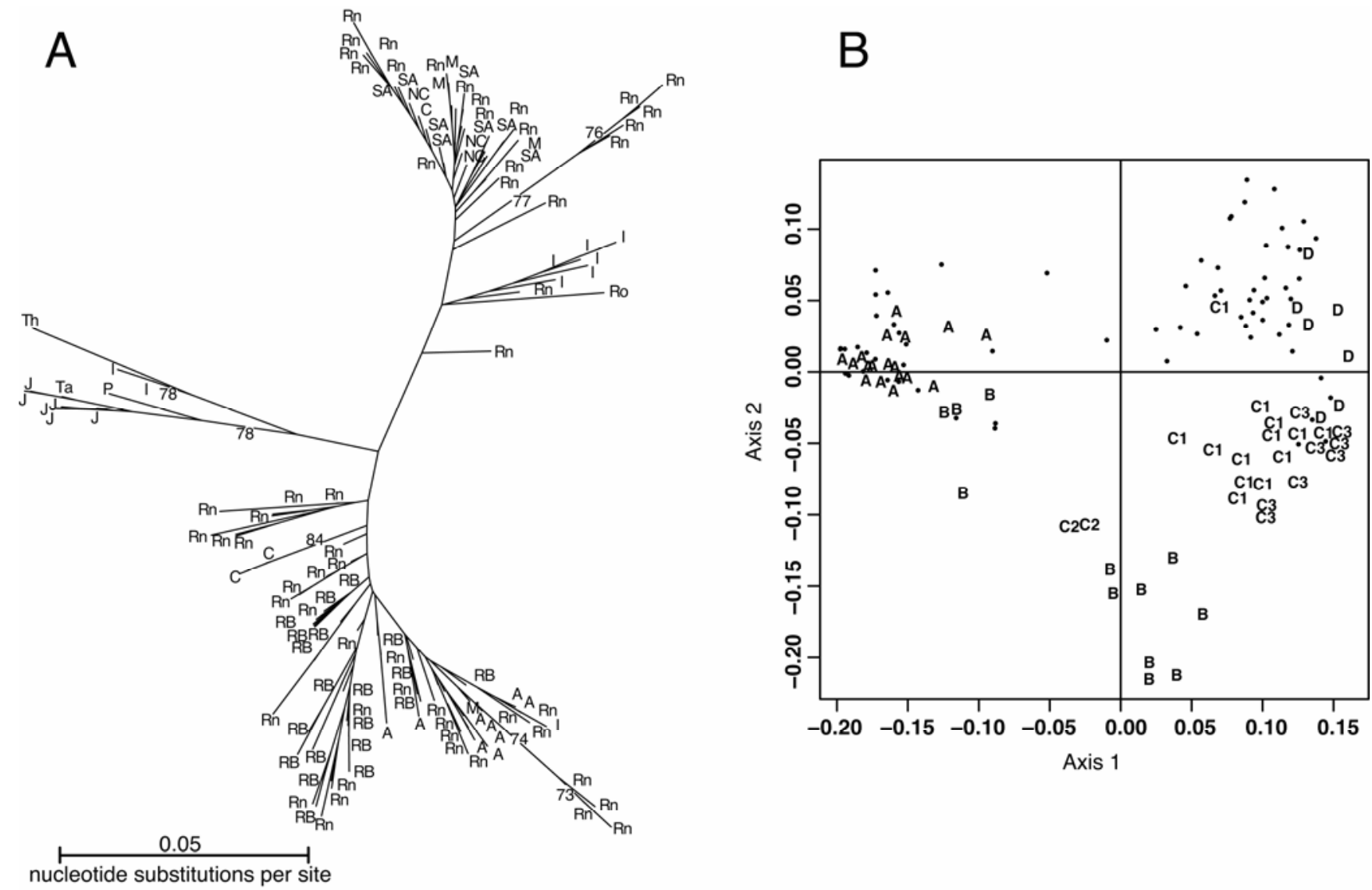

Fig. 2. Genetic diversity among strains of pv. mangiferaeindicae based on amplified fragment length polymorphism data using four pairs of primers. A, Neighborjoining tree based on Jaccard similarity index showing the genetic relatedness among the 125 identified haplotypes from several geographic areas. All strains originated from mango, except where stated. A, Australia; C, Comoros; I, India, J, Japan; M, Mauritius; NC, New Caledonia; P, Philippines; Rn, Réunion; Ro, Rodrigues; Ta, Taiwan; Th, Thailand; and RB, Reunion from Brazilian pepper. B, Multidimensional scaling (MDS) representation of the distances between 125 haplotypes from several geographic areas. The presented two-dimensional MDS has a stress value of 0.045 (1). Corresponding restriction fragment length polymorphism (RFLP) groups (14) are indicated, when available. Three RFLP groups (A, B, and C) contained strains isolated from mango, whereas strains classified in RFLP group D originated from Brazilian pepper. 
lesions) only when inoculated with group I strains originating from this host species. AUDPC values summarizing lesion development of selected group I, II, and III strains are presented in Table 2. Except for interactions involving group III strains, large AUDPC values primarily indicated an earlier development of lesions, as maximal incidence values were reached after 5 to 15 dai. Although significant differences among strains were observed, AUDPCs were not very helpful at clarifying distinctive pathogenicity between groups of strains.

On mango cv. Maison Rouge, large population densities (ranging from $5 \times 10^{6}$ to $9 \times 10^{6} \mathrm{CFU}$ per lesion) were observed only for group I strains originating from mango (Table 4). Population sizes from all other strains were $1 \times 10^{5} \mathrm{CFU}$ per lesion or lower (Table 4). Similar results were obtained from inoculations of mango cv. Haden. On this cultivar, mean population sizes estimated for group II strains from mango (CFBP 2912, 2913 , and 2914) ranged from $5 \times 10^{4}$ to $2 \times 10^{5}$ CFU per lesion, whereas the population size calculated for the group I pathotype strain (CFBP 1716) was $1 \times 10^{7} \mathrm{CFU}$ per lesion.

In contrast, lesions produced on cashew after inoculation with all group II strains developed large population sizes, ranging from
$3 \times 10^{7}$ to $9 \times 10^{7} \mathrm{CFU}$ per lesion (Table 4). Similarly, group I strains originating from mango multiplied to high population densities in cashew $\left(2 \times 10^{7}\right.$ to $3 \times 10^{7} \mathrm{CFU}$ per lesion) (Table 4), but the group I strain CFBP 2939 originating from Brazilian pepper did not $\left(7 \times 10^{4} \mathrm{CFU}\right.$ per lesion) (Table 4$)$.

On Brazilian pepper, the only strains that induced lesions in which large population sizes $\left(7 \times 10^{7}\right.$ to $2 \times 10^{8} \mathrm{CFU}$ per lesion) (Tables 4 and 5) were recorded were group I strains originating from Brazilian pepper. All other strains induced lesions in which populations sizes were significantly smaller, but a larger diversity in population size was found on this host species (Tables 4 and 5). Within group I strains, although population sizes obtained for mango strains were significantly lower than those obtained for Brazilian pepper strains, the former strains still reached relatively high levels, ranging from $4 \times 10^{5}$ to $6 \times 10^{6} \mathrm{CFU}$ per lesion (Table 5).

Pathogenicity tests on ambarella and mombin. Both strains originating from ambarella induced severe dieback of inoculated ambarella plants. No symptom was observed after inoculation of strain $X$. campestris pv. mangiferaeindicae CFBP 1716 or CFBP 2913. On mombin, less severe symptoms were observed. The two strains originating from ambarella induced twig lesions that were

TABLE 4. Population sizes recorded from leaf lesions 35 days after inoculation of three host species with xanthomonads originating from Anacardiaceae and identified as amplified fragment length polymorphism (AFLP) groups 9.4, 9.5, and 9.6 of Xanthomonas axonopodis ${ }^{\mathrm{u}}$

\begin{tabular}{|c|c|c|c|c|c|c|}
\hline \multirow[b]{2}{*}{ Strain } & \multirow[b]{2}{*}{ Host of origin } & \multirow{2}{*}{$\begin{array}{l}\text { Proposed pathovar } \\
\text { designation }^{v}\end{array}$} & \multirow[b]{2}{*}{ AFLP group ${ }^{w}$} & \multicolumn{3}{|c|}{ Log-transformed CFU ml ${ }^{-1}$ species inoculated } \\
\hline & & & & Mango & Cashew & Brazilian pepper \\
\hline CFBP $1716^{x}$ & Mango & mangiferaeindicae $(\mathrm{I})$ & 9.5 & $6.88(0.62)^{\mathrm{y}} \mathrm{a}^{\mathrm{z}}$ & $7.51(0.20) \mathrm{d}$ & $6.67(0.49) b$ \\
\hline JK147-1 & Mango & mangiferaeindicae $(\mathrm{I})$ & 9.5 & $6.97(0.48) \mathrm{a}$ & $7.34(0.27) \mathrm{e}$ & $5.80(0.67) \mathrm{c}$ \\
\hline A5-1 & Mango & mangiferaeindicae (I) & 9.5 & $6.70 \pm 0.61) a$ & $7.53(0.16) \mathrm{d}$ & $6.00(0.84) \mathrm{cd}$ \\
\hline CFBP 2939 & Brazilian pepper & mangiferaeindicae (I) & 9.5 & $4.21(0.51) \mathrm{cd}$ & $4.82(0.21) \mathrm{g}$ & $7.86(0.29) \mathrm{a}$ \\
\hline CFBP 2912 & Mango & anacardii (II) & 9.6 & $4.68(0.69) \mathrm{b}$ & $7.92(0.34) \mathrm{ab}$ & $3.38(0.45) \mathrm{e}$ \\
\hline CFBP 2913 & Mango & anacardii (II) & 9.6 & $4.11(1.16) \mathrm{d}$ & $7.92(0.26) \mathrm{a}$ & $5.72(0.14) \mathrm{c}$ \\
\hline CFBP 2914 & Mango & anacardii (II) & 9.6 & 4.99 (1.33) bc & $7.93(0.22) \mathrm{a}$ & $5.82(0.32) \mathrm{c}$ \\
\hline JY542 & Cashew & anacardii (II) & 9.6 & $4.71(1.06) b c$ & $7.80(0.19) \mathrm{abc}$ & $3.21(0.93)$ ef \\
\hline LA98 & Cashew & anacardii (II) & 9.6 & $3.65(0.39) \mathrm{de}$ & $7.66(0.25) \mathrm{c}$ & $5.27(0.53) \mathrm{d}$ \\
\hline LA99 & Cashew & anacardii (II) & 9.6 & $3.61(0.70) \mathrm{de}$ & $7.80(0.22) a b c$ & $2.58(0.39) \mathrm{g}$ \\
\hline LA100 & Cashew & anacardii (II) & 9.6 & $2.90(0.78) \mathrm{f}$ & $7.73(0.22) b$ & $2.83(0.83) \mathrm{f}$ \\
\hline LA101 & Cashew & anacardii (II) & 9.6 & $3.53(0.81) \mathrm{de}$ & $7.83(0.14) a b$ & $2.96(0.47) \mathrm{f}$ \\
\hline LA102 & Cashew & anacardii (II) & 9.6 & $3.18(1.43) \mathrm{f}$ & $7.70(0.13) \mathrm{c}$ & $2.66(1.04) \mathrm{f}$ \\
\hline LA103 & Cashew & anacardii (II) & 9.6 & $3.33(1.22)$ ef & $7.45(0.27) \mathrm{de}$ & $2.57(0.66) \mathrm{g}$ \\
\hline CFBP 2547 & Ambarella & spondiae (III) & 9.4 & $4.72(0.86) b$ & $6.01(0.43) \mathrm{f}$ & $2.94(0.63)$ ef \\
\hline
\end{tabular}

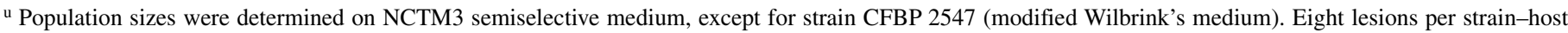
combination were used for population size assessment.

${ }^{v}$ Pathogenicity groups are given in brackets.

w This study. Group numbers as defined in Rademaker et al. $(33,34)$.

x Pathotype strain.

y Standard deviation, based on two replicated experiments.

${ }^{\mathrm{z}}$ Strain comparisons based on Mann-Whitney tests. Population size values with the same letter(s) are not significantly different $(P=0.05)$.

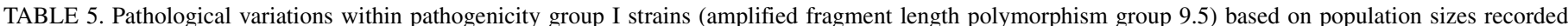
from leaf lesions 35 days after inoculation of two host species

\begin{tabular}{|c|c|c|c|c|c|}
\hline \multirow[b]{2}{*}{ Strain } & \multirow[b]{2}{*}{ Host of origin } & \multirow[b]{2}{*}{ Country of origin } & \multirow{2}{*}{$\begin{array}{l}\text { Restriction fragment length } \\
\text { polymorphism group }{ }^{\mathrm{w}}\end{array}$} & \multicolumn{2}{|c|}{ Log-transformed CFU ml ${ }^{-1}$ species inoculated } \\
\hline & & & & Mango & Brazilian pepper \\
\hline CFBP 2935 & Mango & Australia & $\mathrm{C}$ & $6.68(0.26)^{x} c^{y}$ & $6.69(0.26) \mathrm{cd}$ \\
\hline CFBP $1716^{z}$ & Mango & India & $\mathrm{C}$ & $7.14(0.23) b$ & $6.61(0.45) \mathrm{cd}$ \\
\hline JK147-1 & Mango & Philippines & $\mathrm{B}$ & $7.02(0.48) b$ & $5.81(0.66)$ ef \\
\hline A5-1 & Mango & Réunion & A & $7.38(0.38) \mathrm{a}$ & $5.79(0.64) \mathrm{f}$ \\
\hline CFBP 2932 & Mango & Réunion & $\mathrm{A}$ & $7.58(0.33) \mathrm{a}$ & $5.56(0.67) \mathrm{f}$ \\
\hline CFBP 2933 & Mango & Réunion & $\mathrm{C}$ & $7.38(0.32) \mathrm{a}$ & $6.75(0.41) c$ \\
\hline JV1121 & Mango & South Africa & ND & $6.69(0.31) \mathrm{c}$ & $6.35(0.51) \mathrm{de}$ \\
\hline CFBP 2938 & Brazilian pepper & Réunion & $\mathrm{D}$ & $4.26(0.50) \mathrm{d}$ & $7.97(0.14) b$ \\
\hline CFBP 2939 & Brazilian pepper & Réunion & $\mathrm{D}$ & $3.62(0.46) \mathrm{f}$ & $8.16(0.22) \mathrm{a}$ \\
\hline CFBP 2940 & Brazilian pepper & Réunion & $\mathrm{D}$ & $3.85(0.44) \mathrm{e}$ & $7.99(0.30) b$ \\
\hline JP742 & Brazilian pepper & Réunion & $\mathrm{D}$ & $7.10(0.60) b$ & $8.21(0.18) \mathrm{a}$ \\
\hline JP758 & Brazilian pepper & Réunion & $\mathrm{D}$ & $4.19(0.42) \mathrm{d}$ & $8.06(0.32) a b$ \\
\hline
\end{tabular}

v Population sizes were determined on KC semiselective medium. Eight lesions per strain-host combination were used for population size assessment.

w From Gagnevin and Pruvost (14); ND, not determined.

x Standard deviation, based on two replicated experiments.

y Strain comparisons based on Mann-Whitney tests. Population size values with the same letter(s) are not significantly different $(P=0.05)$.

${ }^{z}$ Pathotype strain. 
approximately 70 to $80 \mathrm{~mm}$ in length 1 month after inoculation, whereas the two strains originating from mango did not cause any lesions. Typical slow-growing nonpigmented colonies were successfully reisolated from assayed lesions.

\section{DISCUSSION}

We used AFLP, a technique that has been extensively used to investigate the species classification of the genus Xanthomonas $(19,33,41)$, intrapathovar assessment of genetic diversity $(6,35)$, and epidemiology (18). Recently, this technique was given emphasis for species delineation in bacterial taxonomy (48). Based on AFLP data, the pathovar mangiferaeindicae was genetically heterogeneous and consisted of three distinct groups of strains. Genetic diversity between strains within group I and group II was low, with maximum EGD values of 0.014 and 0.022 nucleotide substitutions per site, respectively. These values are consistent with those previously published for $X$. arboricola pv. pruni (6) and $X$. axonopodis pv. allii (41). AFLP results further suggested that the provisional designation of strains of pathovar mangiferaeindicae as members of $X$. campestris requires revision, as evolutionary genome divergence of strains of this pathovar with the type strain of $X$. campestris was always higher than 0.130 nucleotide substitutions per site. Likewise, the EGD value between the pathotype strain of $X$. campestris pv. mangiferaeindicae and the type strain of $X$. axonopodis was 0.149 nucleotide substitutions per site. Indeed, EGD values between strains of $X$. campestris pv. mangiferaeindicae and strains of $X$. axonopodis sensu Vauterin et al. (49) were variable, ranging from approximately 0.03 to 0.15 nucleotide substitutions per site.

AFLP data, which show a good correlation with DNA:DNA hybridization data (33), allowed the allocation of pathovar mangiferaeindicae strains within genetic groups of $X$. axonopodis, as defined by Rademaker et al. (34). The pathotype strain of pathovar mangiferaeindicae, together with all strains isolated from the family Anacardiaceae in the Old World (designated herein as group I), were genetically related to $X$. axonopodis group 9.5 (composed of pathovars citri, malvacearum, glycines...), whereas strains isolated from mango and cashew in Brazil (designated herein as group II) were genetically related to $X$. axonopodis group 9.6 (composed of pathovars aurantifolii, phaseoli var. fuscans, vignicola...). Finally, strains isolated from ambarella in the French West Indies (designated herein as group III) were genetically related to $X$. axonopodis group 9.4 (composed of pathovars dieffenbachiae, manihotis, phaseoli...).

One aim of this paper was to clarify the pathovar classification of xanthomonads associated with the family Anacardiaceae. Pathovar mangiferaeindicae was originally characterized as a pathogen of mango (11). In the original description of this pathogen (25), inoculation of other genera in the family Anacardiaceae with mango strains suggested these as putative host species although disease had not been observed on them in the field. In these early reports, pathogenicity was probably assessed solely on the basis of lesion development after inoculation.

AUDPC has been used to quantify pathogenicity tests under controlled environmental conditions. Among xanthomonads, AUDPC was primarily used on vascular pathogens $(2,9,20,36)$, and large AUDPC values were interpreted as successful interactions involving an aggressive pathogen and a susceptible host species. We used AUDPC for characterizing interactions involving foliar pathogens. Interestingly, successful interactions, as determined by population sizes in leaf lesions 35 dai, were characterized by low AUDPC values due to a delayed, rather than an incomplete, lesion development. Conversely, large AUDPC values, due to early lesion development, were correlated with low population sizes 35 dai. This can be interpreted as an early, though moderate, host defense-related necrosis (responsible for the marked population drop observed later during the interaction) rather than a high susceptibility to the pathogen. These results agree with previous data indicating that lesion development after inoculation with group I strains was faster on a partially resistant (cv. Heidi) than on a susceptible (cv. Haden) mango cultivar (31).

Xanthomonads isolated from mango and cashew in Brazil (designated as group II in this study) were originally included in pathovar mangiferaeindicae (38). They formed a homogenous group based on their host range, symptomology, and internal population sizes in leaf lesions on the three Anacardiaceae genera used in this study. When two mango cultivars with different genetic backgrounds were inoculated with these strains, the resulting pathogenicity phenotypes were distinct from that caused by group I strains: leaf lesions were flat, larger AUDPC values were attained, and bacterial population sizes were of $1 \times 10^{4}$ to $1 \times 10^{5} \mathrm{CFU}$ per lesion, typical of interactions involving nonhost species, resistant cultivars, or interactions involving casual pathogens $(4,12,16)$. Similar population sizes were recovered from black lesions 1 month after inoculation of mango leaves in an incompatible interaction with $X$. vesicatoria CFBP 1545 (O. Pruvost, unpublished data). The atypical symptomology described herein on mango leaves for group II strains is consistent with the markedly different disease expression reported in the field on mango leaves, fruits, and twigs in Brazil versus the Old World $(15,43)$. When cashew was inoculated with group II strains, bacterial population sizes in leaf lesions ranged from $3 \times 10^{7}$ to $9 \times 10^{7}$ CFU per lesion, typical of a compatible interaction $(4,12,16)$. Interestingly, cashew originated from Northeastern Brazil (21), whereas mango originated from Asia (23). Brazil appears to be the only country in which epidemics caused by xanthomonads have been reported on cashew (24). Cashew may therefore be the primary host species of xanthomonads genetically related to $X$. axonopodis group 9.6 and isolated from cashew and mango in Brazil. In contrast, data from our study suggest that the pathogen is casual on mango cvs. Haden and Maison Rouge, although field observations from Brazil suggest that the susceptibility of mango to this pathogen may be cultivar-dependent (J. R. Neto, unpublished data). Further quantitative pathogenicity tests are needed to test this hypothesis. Symptomology differences between group II and group I (including the pathotype strain) strains warrant different pathovar designations, as was previously done for $X$. oryzae pv. oryzae and $X$. oryzae pv. oryzicola (11). The proposed pathovar designation for the group II strains is $X$. axonopodis pv. anacardii, as these strains from Brazil shared a high genetic relatedness with members of $X$. axonopodis group 9.6 by AFLP. The elevation of pathovars of $X$. axonopodis group 9.6 as $X$. fuscans proposed by Schaad et al. $(44,45)$ has not been validated to date in the list of prokaryotic names with standing in nomenclature (the International Committee on the Systematics of Prokaryotes [ICSP]). The proposed common name for the associated disease is cashew bacterial spot. The two available yellow-pigmented xanthomonads isolated from mango in Brazil are not included within $X$. axonopodis pv. anacardii, as the EGD values between the nonpigmented and the yellowpigmented strains differed by more than 0.10 nucleotide substitutions per site (i.e., these strains should likely not be classified as $X$. axonopodis).

Similarly, when mango, cashew, or Brazilian pepper were inoculated with strain CFBP 2547 (group III) originating from ambarella, the resulting lesions were small, flat, black, and necrotic. Population sizes recovered from leave lesions on these three Anacardiaceae were $5 \times 10^{4}, 1 \times 10^{6}$, and $9 \times 10^{2} \mathrm{CFU}$ per lesion, respectively. Group III strains induced a severe dieback of ambarella, consistent with previous data (40) and induced extensive twig lesions on mombin. Therefore, group III strains, which are genetically related to $X$. axonopodis group 9.4, induced a unique symptomology on Spondias spp., a characteristic that warrants their being designated $X$. axonopodis pv. spondiae. 
Consequently, we propose that the pathovar mangiferaeindicae epithet be used for characterizing strains truly pathogenic to mango and strains pathogenic to Brazilian pepper (group I strains). We propose that these strains be classified in a single pathovar, as there was a broad variation of population sizes between strains of the same host origin, resulting in a situation where there was less difference in pathogenicity on a given host between the most aggressive heterologous strain and the least aggressive homologous strain than between the least and the most aggressive strains of one type. Moreover, differences in population sizes measured for homologous and heterologous interactions appeared strain-dependent.

These strains shared a high level of genetic relatedness with several pathovars of $X$. axonopodis group 9.5. Therefore, we propose that these strains be provisionally named $X$. axonopodis pv. mangiferaeindicae, as the elevation of pathovars of $X$. axonopodis group 9.5 as $X$. citri recently proposed by Schaad et al. (45) has not yet been validated in the list of prokaryotic names with standing in nomenclature (ICSP). To avoid confusion with the disease caused by $X$. axonopodis pv. anacardii, we recommend that the disease caused by $X$. axonopodis pv. mangiferaeindicae be referred to as mango bacterial canker $(13,46)$ (consistent with the branch cankers and the raised leaf and fruit lesions induced by this pathogen) rather than mango bacterial black spot.

The three proposed Xanthomonas pathovars associated with the family Anacardiaceae can be clearly distinguished by means of phenotypic (29), isozyme (47), RFLP (14), and AFLP (this study) analyses.

The genetic diversity of $X$. axonopodis pv. mangiferaeindicae was assessed, based on AFLP analysis of 325 strains isolated from mango in different countries and from Brazilian pepper in Réunion Island. The multidimensional scaling representation showed three groups of strains that are largely consistent with those previously described using the RFLP technique with two probes: an avirulence gene of the $a v r B s 3$ family and the insertion sequence IS1595 (14). Both AFLP and RFLP strongly suggested interregional or international migration events. Eleven different haplotypes were identified in more than a single country. This involved South Africa, New Caledonia, Australia, Réunion Island, and Mauritius. Probably more countries were concerned by introduction of new strains from foreign countries, but these events were not detected in our study, primarily because the sample size markedly varied among countries. It is likely that some strains today present in Réunion Island were introduced from South Africa, as there were many mango budwood introductions in Réunion Island from South Africa in the 1970s, for which the quarantine conditions are not known. Similarly, there are propagative material exchanges between Réunion Island and its neighbor Mauritius. This could explain why both islands shared identical haplotypes. X. axonopodis pv. mangiferaeindicae can survive asymptomatically in association with mango buds. It was previously shown, using a marked strain, that populations present in/or mango buds were responsible for subsequent leaf lesions on the neo-formed leaves (30).

Description of $X$. axonopodis pv. anacardii. $X$. axonopodis pv. anacardii [a.na'car.di.i N.L. adj. anacardii from Anacardium, the genus of cashew (Anacardium occidentale L.).

Based on AFLP, the bacterium is genetically related to members of $X$. axonopodis group 9.6 sensu Rademaker (34). Its genome does not contain insertion elements of the IS1595 family. Strains of pv. anacardii can also be distinguished from pathovars mangiferaeindicae and spondiae by isozyme analysis (47).

On cashew, characteristic leaf lesions induced by $X$. axonopodis pv. anacardii start as small, angular, water-soaked spots, which extend and eventually coalesce. Lesions turn into necrotic, flat, dark brown spots. No lesions have been reported on other plant organs. On mango, the bacterium produces necrotic, flat, dark brown to black spots, but in contrast with cashew, no initial water- soaked lesions were observed after inoculation of cvs. Maison Rouge and Haden. One month after inoculation, small population sizes (typically $10^{4} \mathrm{CFU}$ per lesion) can be recovered from mango leaf lesions, whereas large population sizes (typically $10^{7} \mathrm{CFU}$ per lesion) can be recovered from cashew leaf lesions. Few reports from Brazil mentioned mango fruit lesions (43), and they described black, depressed and rounded lesions of different sizes. Some lesions only display depressions, with no other external changes, but show an internal pulp decay consisting in tissue discoloration sometimes associated with a pulp rot. Therefore, symptomology on mango fruit is also markedly different from that reported for pv. mangiferaeindicae, as no internal breakdown was observed for this pathogen (15). Finally, Xanthomonas axonopodis pv. anacardii induces unique twig symptoms, i.e. yellow to brown lesions, which subsequently longitudinally crack and evolve as a generalized dieback of the youngest vegetative flush (43). Based on pathogenicity tests and field observations, mango (Mangifera indica) and Brazilian pepper (Schinus terebinthifolius) are not susceptible host species of Xanthomonas axonopodis pv. anacardii.

The proposed neopathotype strain is ICMP 4088 (International Collection of Micro-organisms from Plants, New Zealand) = CFBP 2913 (Collection Française de Bactéries Phytopathogènes, France).

Description of $X$. axonopodis pv. mangiferaeindicae. $X$. axonopodis pv. mangiferaeindicae [man'gi.fe.rae.'in.di.cae N.L. adj. mangiferaeindicae from Mangifera indica L., the Latin binomial of mango.

Based on AFLP, the bacterium is genetically related to members of $X$. axonopodis group 9.5 sensu Rademaker (34). Its genome contains a large number of insertion elements of the IS1595 family. Strains of pv. mangiferaeindicae can also be distinguished from pvs. anacardii and spondiae by isozyme analysis (47).

Bacterial canker affects all aerial parts of the mango plant. The bacterial pathogen can infect through wounds and natural openings. Leaf and fruit symptoms are most common, but twig and branch cankers may occur when infection is severe (i.e., on highly susceptible cultivars). Leaf symptoms begin as small water-soaked spots delineated by veins, becoming raised, black, sometimes with a chlorotic halo. Individual lesions are usually smaller than $0.5 \mathrm{~cm}^{2}$, but they may coalesce to form larger necrotic areas. One month after inoculation, population sizes ranging from $1 \times 10^{6}$ to $1 \times 10^{8} \mathrm{CFU}$ per lesion can be recovered from mango leaf lesions on susceptible cultivars. Several months after infection, leaf lesions dry and turn light brown ash-gray. Severe leaf infection may result in early abscission. Fruit symptoms appear as small water-soaked spots on lenticels. These spots later become star-shaped, erumpent, and exude an infectious gum. Often, a "tear stain" infection pattern is observed on the fruit. Severe fruit infections will cause premature fruit drop. Twig cankers are potential sources of inoculum and weaken branch resistance to winds, but such lesions seem to occur only when climatic events (such as tropical storms) are responsible for massive inoculum redistribution and wounds. The disease is not systemic and does not affect the root.

Although inducing leaf lesions after inoculation, $X$. axonopodis pv. mangiferaeindicae has never been isolated in the field from Anacardium spp. and Spondias spp. Brazilian pepper (Schinus terebinthifolius) is considered a host species of $X$. axonopodis $\mathrm{pv}$. mangiferaeindicae, although a host specialization occurs for most, but not all, strains.

The pathotype strain is ATCC 11637 (American Type Culture Collection, MD) = CFBP 1716 = ICMP 5740 (International Collection of Micro-organisms from Plants, New Zealand) = BCCM-LMG 941 (Belgian Coordinated Collections of Microorganisms, University of Ghent, Belgium) = NCPPB 490 (National Collection of Plant Pathogenic Bacteria, UK). 
Description of $X$. axonopodis pv. spondiae. $X$. axonopodis pv. spondiae ['spon.di.ae N.L. adj. spondiae from Spondias, the genus of ambarella (Spondias cytherea Sonn.) and mombin (Spondias mombin L.).

Based on AFLP, the bacterium is genetically related to members of $X$. axonopodis group 9.4 sensu Rademaker (34). Its genome does not contain insertion elements of the IS1595 family. Strains of pv. spondiae can also be distinguished from pvs. anacardii and mangiferaeindicae by isozyme analysis (47).

On ambarella, characteristic leaf lesions induced by $X$. axonopodis pv. spondiae start as small, angular, water-soaked spots, which extend and eventually coalesce. Lesions turn into necrotic, flat, dark brown spots, sometimes delineated by the veins. On stems, water-soaked lesions, which turn into extensive cankers, are frequently found. Orange gummy exudates oozing from twig cankers are frequently observed. Numerous twig cankers can induce a severe dieback of ambarella trees. No fruit lesions have been reported. Based on pathogenicity tests, Spondias mombin displayed similar symptoms, but appeared less susceptible to the pathogen. In the French West Indies, the only territory where $X$. axonopodis pv. spondiae has been reported to date (40), no lesions were observed on mango trees.

The proposed neopathotype strain is CFBP 2547 (Collection Française de Bactéries Phytopathogènes, INRA Angers, France), = LMG 17211 (Belgian Coordinated Collections of Microorganisms, University of Ghent, Belgium).

\section{ACKNOWLEDGMENTS}

We thank J. Young, X. Nesme, C. Vernière, and M. Grisoni for helpful discussion and/or manuscript review before submission; G. Burkhart and J. Young for proofreading in English; B. Manicom, S. Benimahdu, S. Gnanamanickam, J. Brinon, P. Fahy, M. Moffett, J. Moll, C. d'Ursel, and W. Wu for providing us with bacterial strains; and C. Boyer, K. Vital, V. Ledoux, A. Tailamé, J. Acapandié, W. Grondin, and F. Mondon for technical assistance. The European Union (FEOGA), Conseil Régional de La Réunion, and CIRAD provided financial support.

\section{LITERATURE CITED}

1. Abdi, H. 2007. Metric multidimensional scaling (MDS): Analyzing distance matrices. In: Encyclopedia of Measurement and Statistics. N. Salkind, ed. Sage, Thousand Oaks, CA.

2. Adhikari, T. B., Shrestha, A., Basnyat, R. C., and Mew, T. W. 1999. Use of partial host resistance in the management of bacterial blight of rice. Plant Dis. 83:896-901.

3. Barbosa, F. R., Haji, F. N. P., De Alencar, J. A., Moreira, A. N., De Tavares, S. C. C., Lima, M. F., and Moreira, W. A. 2000. Monitoramento de pragas e doenças na cultura da mangueira. Page 33 in: Embrapa SemiÁrido. Documentos Embrapa Semi-Árido, Petrolina, PE.

4. Bayles, M. B., and Johnson, W. M. 1985. Growth of homologous and heterologous phytopathogenic bacteria in cotton lines susceptible, resistant, or immune to blight. Phytopathology 75:515-519.

5. Boon, N., De Windt, W., Verstraete, W., and Top, E. M. 2002. Evaluation of nested PCR-DGGE (denaturing gradient gel electrophoresis) with group-specific 16S rRNA primers for the analysis of bacterial communities from different wastewater treatment plants. FEMS Microbiol. Ecol. 39:101-112.

6. Boudon, S., Manceau, C., and Notteghem, J. L. 2005. Structure and origin of Xanthomonas arboricola pv. pruni populations causing bacterial spot of stone fruit trees in Western Europe. Phytopathology 95:1081-1088.

7. Brehm, G., Homeier, J., and Fiedler, K. 2003. Beta diversity of geometrid moths (Lepidoptera: Geometridae) in an Andean montane rainforest. Divers. Distrib. 9:351-366.

8. Campbell, C. L., and Madden, L. V. 1990. Temporal analysis of epidemics. I: Description and comparison of disease progress curves. Pages 161-202 in: Introduction to Plant Disease Epidemiology. John Wiley \& Sons, New York.

9. Champoiseau, P., Daugrois, J. H., Girard, J. C., Royer, M., and Rott, P. C. 2006. Variation in albicidin biosynthesis genes and in pathogenicity of Xanthomonas albilineans, the sugarcane leaf scald pathogen. Phytopathology 96:33-45.

10. Doidge, E. M. 1915. A bacterial disease of the mango Bacillus mangiferae n. sp. Ann. Appl. Biol. 2:1-44.
11. Dye, D. W., Bradbury, J. F., Goto, M., Hayward, A. C., Lelliott, R. A., and Schroth, M. N. 1980. International standards for naming pathovars of phytopathogenic bacteria and a list of pathovar names and pathotype strains. Rev. Plant Pathol. 59:153-168.

12. Egel, D. S., Graham, J. H., and Riley, T. D. 1991. Population dynamics of Xanthomonas campestris differing in aggressiveness on Swingle citrumelo and grapefruit. Phytopathology 81:666-671.

13. Fukuda, T., Uehara, K., Azegami, K., Tabei, H., and Nishiyama, K. 1990. Bacterial canker of Mango in Japan caused by Xanthomonas campestris pv. mangiferaeindicae. Ann. Phytopathol. Soc. Jpn. 56:474-480.

14. Gagnevin, L., Leach, J. E., and Pruvost, O. 1997. Genomic variability of the Xanthomonas pathovar mangiferaeindicae, agent of mango bacterial black spot. Appl. Environ. Microbiol. 63:246-253.

15. Gagnevin, L., and Pruvost, O. 2001. Epidemiology and control of mango bacterial black spot. Plant Dis. 85:928-935.

16. Groth, D. E., and Braun, E. J. 1986. Growth kinetics and histopathology of Xanthomonas campestris pv. glycines in leaves of resistant and susceptible soybeans. Phytopathology 76:959-965.

17. Hopkins, C. M., White, F. F., Choi, S. H., Guo, A., and Leach, J. E. 1992. Identification of a family of avirulence genes from Xanthomonas oryzae pv. oryzae. Mol. Plant-Microbe Interact. 5:451-459.

18. Humeau, L., Roumagnac, P., Picard, Y., Robène-Soustrade, I., Chiroleu, F., Gagnevin, L., and Pruvost, O. 2006. Quantitative and molecular epidemiology of bacterial blight of onion in seed production fields. Phytopathology 96:1345-1354.

19. Janssen, P., Coopman, R., Huys, G., Swings, J., Bleeker, M., Vos, P., Zabeau, M., and Kersters, K. 1996. Evaluation of the DNA fingerprinting method AFLP as a new tool in bacterial taxonomy. Microbiology 142:1881-1893.

20. Michel, V. V. 2001. Interactions between Xanthomonas campestris pv. graminis strains and meadow fescue and Italian rye grass cultivars. Plant Dis. $85: 538-542$.

21. Morton, J. F. 1987. Cashew apple. Pages 239-240 in: Fruits of Warm Climates. J. F. Morton, ed. Creative Resource Systems, Inc., Winterville, NC.

22. Mougel, C., Thioulouse, J., Perrière, G., and Nesme, X. 2002. A mathematical method for determining genome divergence and species delineation using AFLP. Int. J. Syst. Evol. Microbiol. 52:573-586.

23. Mukherjee, S. K. 1997. Introduction: Botany and importance. Pages 1-21 in: The Mango: Botany, Production and Uses. R. E. Litz, ed. CAB International, Oxon, New York.

24. Papa, M. F. S., Matos, E. C., Almeida, I. M. G., Malavolta, V. A., Jr., and Boliani, A. C. 2001. Ocorrencia da mancha angular (Xanthomonas campestris pv. mangiferaeindicae) em cajueiro no estado do Mato Grosso do Sul. Summa Phytopathol. 27:117.

25. Patel, M. K., Kulkarni, Y. S., and Moniz, L. 1948. Pseudomonas mangiferae-indicae, pathogenic on mango. Indian Phytopathol. 1:147-152.

26. Perrier, X., Flori, A., and Bonnot, F. 2003. Data analysis methods. Pages 43-76 in: Genetic Diversity of Cultivated Tropical Plants. P. Hamon, M. Seguin, X. Perrier, and J. C. Glaszmann, eds. Science, Enfield, NH.

27. Prakash, O., and Misra, A. K. 1992. Important diseases of mango and their effect on production. Biol. Memoirs 18:39-55.

28. Pruvost, O., Couteau, A., and Luisetti, J. 1992. Pepper tree (Schinus terebenthifolius Radii), a new host plant for Xanthomonas campestris pv. mangiferaeindicae. J. Phytopathol. 135:289-298.

29. Pruvost, O., Couteau, A., Perrier, X., and Luisetti, J. 1998. Phenotypic diversity of Xanthomonas sp. mangiferaeindicae. J. Appl. Microbiol. 84:15-24.

30. Pruvost, O., Couteau, A., Vernière, C., and Luisetti, J. 1993. Epiphytic survival of Xanthomonas campestris pv. mangiferaeindicae on mango buds. Acta Hortic. 341:337-344

31. Pruvost, O., Gagnevin, L., Gloriès, V., Couteau, A., Mété, K., and Flahaut, B. 2001. Epidemiology and population structure of Xanthomonas pv. mangiferaeindicae present on partially resistant and susceptible mango cultivars. Paper read at 39th South African Society for Plant Pathology Congress.

32. Pruvost, O., Roumagnac, P., Gaube, C., Chiroleu, F., and Gagnevin, L. 2005. New media for the semi-selective isolation and enumeration of Xanthomonas campestris pv. mangiferaeindicae, the causal agent of mango bacterial black spot. J. Appl. Microbiol. 99:803-815.

33. Rademaker, J. L. W., Hoste, B., Louws, F. J., Kersters, K., Swings, J., Vauterin, L., Vauterin, P., and De Bruijn, F. J. 2000. Comparison of AFLP and rep-PCR genomic fingerprinting with DNA-DNA homology studies: Xanthomonas as a model system. Int. J. Syst. Evol. Microbiol. 50:665-677.

34. Rademaker, J. L. W., Louws, F. J., Schultz, M. H., Rossbach, U., Vauterin, L., Swings, J., and De Bruijn, F. J. 2005. A comprehensive species to strain taxonomic framework for Xanthomonas. Phytopathology 95:10981111

35. Restrepo, S., Duque, M., Tohme, J., and Verdier, V. 1999. AFLP fingerprinting: An efficient technique for detecting genetic variation of Xanthomonas axonopodis pv. manihotis. Microbiology 145:107-114. 
36. Restrepo, S., Duque, M. C., and Verdier, V. 2000. Characterization of pathotypes among isolates of Xanthomonas axonopodis pv. manihotis in Colombia. Plant Pathol. 49:680-687.

37. Robbs, C. F. 1954. Bacterias fitopatogenicas do Brasil. Agronomia 13:265-282.

38. Robbs, C. F., Ribeiro, R. D. L. D., and Kimura, O. 1974. Sobre a posicao taxonomica de Pseudomonas mangiferaeindicae Patel et al. 1948, agente causal da "mancha bacteriana" das folhas da mangueira (Mangifera indica L.). Arq. Univ. Fed. Rur., Rio de Janeiro 4:11-14.

39. Rott, P., Chatenet, M., Granier, M., and Baudin, P. 1988. L'échaudure des feuilles de canne à sucre provoquée par Xanthomonas albilineans (Ashby) Dowson. II - Diagnostic et spectre d'hotes de l'agent pathogene en Afrique tropicale. Agron. Trop. 43:244-251.

40. Rott, P., and Frossard, P. 1986. Un chancre bactérien du Prunier de Cythère (Spondias cytherea, Sonn.) en Martinique. Fruits 41:605-613.

41. Roumagnac, P., Gagnevin, L., Gardan, L., Sutra, L., Manceau, C., Dickstein, E. R., Jones, J. B., Rott, P., and Pruvost, O. 2004. Polyphasic characterization of xanthomonads isolated from onion, garlic and Welsh onion (Allium spp.) and their relatedness to different Xanthomonas species. Int. J. Syst. Evol. Microbiol. 54:15-24.

42. Saitou, N., and Nei, M. 1987. The neighbor-joining method: A new method for reconstructing phylogenetic trees. Mol. Biol. Evol. 4:406-425

43. Santos Filho, H. P., De Holanda Tavares, S. C. C., De Matos, A. P., De Oliveira Costa, V. S., Moreira, W. A., and Ferreira dos Santos, C. C. 2002. Doenças, monitoramento e controle. Pages 299-352 in: A Cultura de Mangueira. P. J. De Carvalho Genu and A. C. De Queroz Pinto, eds. Embrapa, Brasilia, DF, Brazil.

44. Schaad, N. W., Postnikova, E., Lacy, G. H., Sechler, A., Agarkova, I., Stromberg, P. E., Stromberg, V. K., and Vidaver, A. K. 2005. Reclassi- fication of Xanthomonas campestris pv. citri (ex Hasse 1915) Dye 1978 forms $\mathrm{A}, \mathrm{B} / \mathrm{C} / \mathrm{D}$, and $\mathrm{E}$ as $X$. smithii subsp. citri (ex Hasse) sp. nov. nom. rev. comb. nov., X. fuscans subsp. aurantifolii (ex Gabriel 1989) sp. nov. nom. rev. comb. nov., and $X$. alfalfae subsp. citrumelo (ex Riker and Jones) Gabriel et al., 1989 sp. nov. nom. rev. comb. nov.; X. campestris pv. malvacearum (ex Smith 1901) Dye 1978 as X. smithii subsp. smithii nov. comb. nov. nom. nov.; X. campestris pv. alfalfae (ex Riker and Jones, 1935) Dye 1978 as X. alfalfae subsp. alfalfae (ex Riker et al., 1935) sp. nov. nom. rev.; and "var. fuscans" of $X$. campestris pv. phaseoli (ex Smith, 1987) Dye 1978 as X. fuscans subsp. fuscans sp. nov. Syst. Appl. Microbiol. 28:494-518.

45. Schaad, N. W., Postnikova, E., Lacy, G. H., Sechler, A., Agarkova, I., Stromberg, P. E., Stromberg, V. K., and Vidaver, A. K. 2006. Emended classification of xanthomonad pathogens on citrus. Syst. Appl. Microbiol. 29:690-695.

46. Shekhawat, G. S., and Patel, P. N. 1975. Studies on bacterial canker of mango. Pflugers Krankh. 3:129-138.

47. Somé, A., and Samson, R. 1996. Isoenzyme diversity in Xanthomonas campestris pv. mangiferaeindicae. Plant Pathol. 45:426-431.

48. Stackebrandt, E., Frederiksen, W., Garrity, G. M., Grimont, P. A. D., Kampfer, P., Maiden, M. C. J., Nesme, X., Rossello-Mora, R., Swings, J., Truper, H. G., Vauterin, L., Ward, A. C., and Whitman, W. B. 2002. Report of the ad hoc committee for the re-evaluation of the species definition in bacteriology. Int. J. Syst. Evol. Microbiol. 52:1043-1047.

49. Vauterin, L., Hoste, B., Kersters, K., and Swings, J. 1995. Reclassification of Xanthomonas. Int. J. Syst. Bacteriol. 45:472-489.

50. Young, J. M., Takikawa, Y., Gardan, L., and Stead, D. E. 1992. Changing concepts in the taxonomy of plant pathogenic bacteria. Annu. Rev. Phytopathol. 30:67-105 